\title{
2 Effects of hypoxia on the energy status and nitrogen metabolism 3 of African lungfish during aestivation in a mucus cocoon
}

\author{
A. M. Loong - S. F. Ang - W. P. Wong $\cdot$ H. O. Pörtner \\ C. Bock $\cdot$ R. Wittig $\cdot$ C. R. Bridges $\cdot$ S. F. Chew $\cdot$ Y. K. Ip
}

Received: 27 October 2007 / Revised: 25 April 2008 / Accepted: 5 May 2008 (C) Springer-Verlag 2008

\begin{abstract}
We examined the energy status, nitrogen metabolism and hepatic glutamate dehydrogenase activity in the African lungfish Protopterus annectens during aestivation in normoxia (air) or hypoxia $\left(2 \% \mathrm{O}_{2}\right.$ in $\left.\mathrm{N}_{2}\right)$, with tissues sampled on day 3 (aerial exposure with preparation for aestivation), day 6 (entering into aestivation) or day 12 (undergoing aestivation). There was no accumulation of ammonia in tissues of fish exposed to normoxia or hypoxia throughout the 12-day period. Ammonia toxicity was avoided by increased urea synthesis and/or decreased endogenous $\mathrm{N}$ production (as ammonia), but the dependency on these two mechanisms differed between the normoxic and the hypoxic fish. The rate of urea synthesis increased 2.4-fold, with only a $12 \%$ decrease in the rate of $\mathrm{N}$ production in the normoxic fish. By contrast, the rate of $\mathrm{N}$ production in the hypoxic fish decreased by $58 \%$, with no increase in the rate of urea synthesis. Using in vivo ${ }^{31} \mathrm{P}$
\end{abstract}

Communicated by I.D. Hume.

A. M. Loong · S. F. Ang · W. P. Wong · Y. K. Ip (莐

Department of Biological Science,

National University of Singapore, Kent Ridge,

Singapore 117543, Singapore

e-mail: dbsipyk@nus.edu.sg

H. O. Pörtner · C. Bock · R. Wittig

Alfred-Wegener-Institute for Marine and Polar Research,

Am Handelshafen 12, 27570 Bremerhaven, Germany

\section{R. Bridges}

Institut für Zoophysiologie, Heinrich-Heine Universität,

40225 Düsseldorf, Germany

\section{S. F. Chew}

Natural Sciences, National Institute of Education,

Nanyang Technological University, 1 Nanyang Walk,

Singapore 637616, Singapore
NMR spectroscopy, it was demonstrated that hypoxia led to significantly lower ATP concentration on day 12 and significantly lower creatine phosphate concentration on days $1,6,9$ and 12 in the anterior region of the fish as compared with normoxia. Additionally, the hypoxic fish had lower creatine phosphate concentration in the middle region than the normoxic fish on day 9. Hence, lowering the dependency on increased urea synthesis to detoxify ammonia, which is energy intensive by reducing $\mathrm{N}$ production, would conserve cellular energy during aestivation in hypoxia. Indeed, there were significant increases in glutamate concentrations in tissues of fish aestivating in hypoxia, which indicates decreases in its degradation and/or transamination. Furthermore, there were significant increases in the hepatic glutamate dehydrogenase (GDH) amination activity, the amination/deamination ratio and the dependency of the amination activity on ADP activation in fish on days 6 and 12 in hypoxia, but similar changes occurred only in the normoxic fish on day 12 . Therefore, our results indicate for the first time that $P$. annectens exhibited different adaptive responses during aestivation in normoxia and in hypoxia. They also indicate that reduction in nitrogen metabolism, and probably metabolic rate, did not occur simply in association with aestivation (in normoxia) but responded more effectively to a combined effect of aestivation and hypoxia.

Keywords Aestivation - Ammonia - Glutamate dehydrogenase $\cdot$ Hypoxia $\cdot$ Lungfish $\cdot$ Nitrogen metabolism . Protopterus annectens $\cdot$ Urea

Abbreviations

ADP

Adenosine diphosphate

ATP Adenosine triphosphate

EDTA Ethylenediaminetetraacetic acid

EGTA Ethylene glycol-tetraacetic acid

\begin{tabular}{|l|l|l|l|lll|}
\hline Large 360 & 273 & xxxx & \multicolumn{2}{|l|}{ Dispatch: 12.5.08 } & \multicolumn{2}{c|}{ No . of Pages: 13} \\
\hline Journal & Article & MS Code & LE $\square$ & TYPESET $\square$ & CP $\square$ & DISK $\square$ \\
\hline
\end{tabular}


Free amino acid

59 GDH

$60 \alpha-K G$

$61 \mathrm{~N}$

62 NADH

63 NAD

$64 \mathrm{NaF}$

$65 \quad{ }^{31} \mathrm{P}$ NMR

66 PMSF

67 TFAA

68 TEFAA

$\alpha$-Ketoglutarate

Nitrogen

Sodium fluoride
Glutamate dehydrogenase

$\beta$-Nicotinamide adenine dinucleotide, reduced

$\beta$-Nicotinamide adenine dinucleotide

${ }^{31}$ Phosphorus nuclear magnetic resonance

Phenylmethyl sulfonyl fluoride

Total free amino acid

Total essential free amino acid

\section{Introduction}

Lungfishes, as members of Class Sarcopterygii, are wellknown for their plausible involvement in water-land transition during evolution. There are six species of extant lungfishes, four of which can be found in Africa. African lungfishes, belonging to Family Protopteridae, possess two lungs and are obligatory air-breathers (Graham 1997). They can often be found in hypoxic waters. Unlike their South American and Australian counterparts, African lungfishes undergo aestivation in the absence of water during drought, and remain incarcerated in this state of inactivity until the return of water to the habitat (Fishman et al. 1987; Ip et al. 2005a). They can aestivate inside a cocoon made of dried mucus in air (Protopterus dolloi, Chew et al. 2004; Protopterus aethiopicus, Ip et al. 2005b; Protopterus annectens, Loong et al. 2008) or burrow into the mud and aestivate in a subterranean cocoon (Protopterus annectens and P. aethiopicus; Janssens 1964; Janssens and Cohen 1968a, b; Loong et al. 2008).

African lungfishes are ureogenic; they possess a full complement of ornithine-urea cycle (OUC) enzymes (Janssens and Cohen 1966, 1968a; Mommsen and Walsh 1989), including carbamoyl phosphate synthetase III (CPS III), in their livers (Chew et al. 2003; Loong et al. 2005). However, they are ammonotelic in water (Lim et al. 2004; Loong et al. 2005; Ip et al. 2005b). During aestivation, ammonia excretion would be impeded, leading to its accumulation in the body. Since ammonia is toxic (Cooper and Plum 1987; Hermenegildo et al. 1996; Ip et al. 2001; Brusilow 2002; Felipo and Butterworth 2002; Rose 2002), African lungfishes have to avoid ammonia toxicity during aestivation, and they achieve this through an increase in urea synthesis (Smith 1930, 1935; Janssens 1964; Janssens and Cohen 1968a, b) and a suppression of $\mathrm{N}$ production as ammonia (see Ip et al. 2004; Chew et al. 2006 for reviews). Recently, Chew et al. (2004) demonstrated that the rate of urea synthesis increased 2.4- to 3.8-fold and the rate of $\mathrm{N}$ production decreased by $72 \%$ in $P$. dolloi during 40 days of aestivation in air (normoxia) when compared with the immersed control.

Urea synthesis is energy intensive; $5 \mathrm{~mol}$ of ATP are required for the formation of one mole of urea. Therefore, increased urea synthesis may not be an effective adaptation in fish aestivating in hypoxic mud, as environmental hypoxia causes a low efficiency of ATP production due to the exploitation of anaerobic pathways (Hochachka 1980). Indeed, Loong et al. (2008) reported that 46 days of aestivation in mud resulted in no changes in tissue urea concentrations in $P$. annectens, which indicates that profound suppressions of urea synthesis and $\mathrm{N}$ production had occurred. Since fish aestivating in mud had low blood $\mathrm{pO}_{2}$ and muscle ATP concentrations, Loong et al. (2008) speculated that they could have been exposed to hypoxia, resulting in greater reductions in metabolic rate and $\mathrm{N}$ production. Consequently, there was a lower dependency on increased urea synthesis to detoxify ammonia in the fish aestivating in mud as compared with those aestivating in air. Therefore, this study was undertaken to evaluate and compare effects of normoxia and hypoxia on tissue energetics and nitrogen metabolism in $P$. annectens during induction (days 3 and 6) or maintenance (day 12) of aestivation under laboratory conditions. On day 3 , the fish was exposed to air and on day 6 the fish would have entered into aestivation with the formation of a completely dried mucus cocoon. Contrary to the proposition of Perry et al. (2008), these experimental fish cannot be regarded as undergoing "terrestrialization", because no water was added to prevent the formation of a completely dried cocoon as in the case of series two experiment performed by Wood et al. (2005). Since we could induce $P$. annectens to aestivate in air-tight plastic boxes, we were able to determine for the first time ATP and creatine phosphate concentrations in various regions of the live fish during 12 days of induction and maintenance of aestivation using in vivo ${ }^{31} \mathrm{P}$ NMR spectroscopy.

Additionally, we determined tissue ammonia and urea concentrations of fish aestivating in normoxia or hypoxia in order to test the hypothesis that the magnitude of increase in urea synthesis and accumulation would be lower in fish aestivating in hypoxia than in normoxia. Traditionally, it has been assumed that metabolic rate reduction naturally occurs in African lungfishes in association with aestivation but without differentiating whether aestivation takes place in hypoxia or normoxia (Smith 1935; Janssens and Cohen 1968a, b). However, Perry et al. (2008) demonstrated that $P$. dolloi aestivating in a completely dried mucus cocoon in air (normoxia) had a respiratory rate comparable to that of control fish immersed in water. We therefore reasoned that there could be a greater reduction in metabolic rate in fish aestivating in hypoxia than in normoxia, resulting in a greater suppression in nitrogen metabolism in the former than in the latter. Hence, the concentrations of free amino acids (FAAs) in various tissues were determined in order to

\begin{tabular}{|c|c|c|c|c|c|c|}
\hline Large 360 & $\overline{273}$ & $\mathbf{x X X X}$ & Dispatc & 2.5 .08 & & of Pages: 13 \\
\hline Journal & Article & MS Code & LE $\square$ & TYPESET $\square$ & CP $\square$ & DISK ఐ \\
\hline
\end{tabular}


deduce indirectly whether there was a larger decrement of amino acid catabolism in fish exposed to hypoxia than to normoxia.

Finally, to confirm that aestivation in hypoxia indeed affected amino acid metabolism in P. annectens, we examined, for the first time, the kinetic properties of glutamate dehydrogenase (GDH), in both amination and deamination directions, from livers of the normoxic and hypoxic fish. GDH catalyzes the amination of $\alpha$-ketoglutarate in the presence of NADH or the deamination of glutamate in the presence of NAD. Glutamate formed by the amination reaction can act as a substrate for transamination of amino acids or the formation of glutamine, which is the substrate of urea synthesis in the hepatic ornithine-urea cycle (Chew et al. 2003; Loong et al. 2005). Conversely, $\alpha$-ketoglutarate produced through glutamate deamination can be shuttled into the tricarboxylic acid cycle for ATP production. Hence, GDH is in a crucial position to regulate the degradation of amino acids and plays an important role in integrating nitrogen and carbohydrate metabolism. Additionally, GDH is known to be activated by ADP (Campbell 1973), the concentration of which may change during hypoxic exposure, and GDH can also be modified by ADP-ribosylation (Herrero-Yraola et al. 2001). Thus, we aimed to test two hypotheses: (1) there could be changes in specific activity and kinetic properties of GDH, in amination and/or deamination directions, from the liver of $P$. annectens during the induction and maintenance phases of aestivation, and (2) these changes might be different between normoxic and hypoxic fishes, especially with regard to ADP activation in vitro. Since Richardson's ground squirrel (Spermophilus richardsonii) possesses two distinct forms of GDH, and its GDH properties change during hibernation (Thatcher and Storey 2001), we aimed to deduce indirectly from the kinetic properties of its hepatic GDH whether different forms of GDH existed in P. annectens.

\section{Materials and methods}

Fish

Protopterus annectens (80-120 g body mass) were imported from Central Africa through a local fish farm in Singapore. Specimens were maintained in plastic aquaria filled with dechlorinated water, containing $2.3 \mathrm{mmol} \mathrm{l}^{-1}$ $\mathrm{Na}^{+}, 0.54 \mathrm{mmol} \mathrm{l}^{-1} \mathrm{~K}^{+}, 0.95 \mathrm{mmol} \mathrm{l}{ }^{-1} \mathrm{Ca}^{2+}, 0.08 \mathrm{mmol}$ $\mathrm{l}^{-1} \mathrm{Mg}^{2+}, 3.4 \mathrm{mmol} \mathrm{l}^{-1} \mathrm{Cl}^{-}$and $0.6 \mathrm{mmol} \mathrm{l}^{-1} \mathrm{HCO}_{3}^{-}$, at $\mathrm{pH}$ 7.0 and at $25^{\circ} \mathrm{C}$ in the laboratory, and water was changed daily. No attempt was made to separate the sexes. Fish were acclimated to laboratory conditions for at least 1 month. During the adaptation period, fish were fed frozen fish meat. In June 2005 and June 2006, fish were transported to
Düsseldorf and then to Bremerhaven under animal experimentation Permit (50.05-230-44/05, Landesamt für Natur, Umwelt und Vebraucherschutz, NRW) for ${ }^{31} \mathrm{P}$ NMR studies.

We succeeded in inducing $P$. annectens to aestivate in the presence of small volumes of water inside air-tight plastic containers continuously flushed with air or a calibrated gas mixture $\left(2 \% \mathrm{O}_{2}\right.$ in $\left.\mathrm{N}_{2}\right)$. With such a set up, we overcame problems associated with controlling the severity and consistency of hypoxic exposure as in the case of experimenting with fish aestivating in mud (as in its natural habitat; Loong et al. 2008). In addition, we eliminated problems associated with the interference of ${ }^{31} \mathrm{P}$ NMR application by mud. Under standard laboratory conditions, the experimental fish would secrete mucus during the first few days, and the mucus would slowly dry up between day 6 and day 7 to form a mucus cocoon. Therefore, three major time points were defined in this study, that is day 3 (preparation for aestivation), day 6 (entering into aestivation) and day 12 (after 5-6 days of aestivation), with additional time points for the in vivo ${ }^{31} \mathrm{P}$ NMR spectroscopy.

Determination of ATP and creatine phosphate concentrations at three different regions of live fish using in vivo ${ }^{31} \mathrm{P}$ NMR spectroscopy

Normoxic fish were exposed individually to terrestrial conditions and allowed to enter into aestivation at $23^{\circ} \mathrm{C}$ in airtight plastic containers $(17.5 \mathrm{~cm} \times 11.5 \mathrm{~cm} \times 5 \mathrm{~cm}$, length $\times$ width $\times$ height) containing $20 \mathrm{ml}$ of water. The head space of boxes was flushed continuously

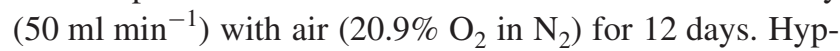
oxic fish underwent aestivation in similar plastic containers but they were flushed with $2 \% \mathrm{O}_{2}$ in $\mathrm{N}_{2}$ instead. The gas was mixed using a gas-mixing pump (Wösthoff, Bochum, Germany). Control measurements were taken before the fish were exposed to terrestrial conditions (day 0), and measurements continued on days 1, 3, 6, 9 and 12 for each individual fish.

In vivo ${ }^{31} \mathrm{P}$ NMR spectroscopy experiments were conducted using a 47/40 Bruker Biospec DBX system with a $40 \mathrm{~cm}$ horizontal wide bore and actively shielded gradient coils $\left(50 \mathrm{mT} \mathrm{m}^{-1}\right)$ (Melzner et al. 2006). A $5 \mathrm{~cm}^{1} \mathrm{H} /{ }^{31} \mathrm{P} /$ ${ }^{13} \mathrm{C}$ surface coil was used for excitation and signal reception. The coil was placed directly under the animal chamber to gain maximum signal from three different regions (anterior, middle and posterior) of the fish. The anterior region of the fish refers to the head; the middle region refers to the location of the liver; and, the posterior region refers to the position before the vent where the kidney is located. It was hoped that results obtained would provide some information on possible changes in the energy status in brain, liver and kidney in addition to possible changes in muscle.

\begin{tabular}{|c|c|c|c|c|c|c|}
\hline Large 360 & 273 & $\mathbf{x x x x}$ & Dispatc & 2.5 .08 & & . of Pages: 13 \\
\hline
\end{tabular}


261 Temperature in the animal chamber inside the magnet was 262 kept at $23^{\circ} \mathrm{C}$ and monitored by a fibre-optic thermometer 263 (Luxtron 504, Polytec, Waldheim, Germany) and recorded 264 via a MacLab system (AD-Instruments, Australia). In vivo $265{ }^{31} \mathrm{P}$ NMR spectra (sweep width, 5,000 Hz; flip angle, 45 , 266 repetition time (TR), $1 \mathrm{~s}$; scans, 256; duration, 4 min $31 \mathrm{~s}$ ) 267 were acquired and an average of four spectra was taken 268 from each region. Concentrations of ATP and creatine 269 phosphate were determined from the NMR spectra accord270 ing to the method of Kemp et al. (2007) and expressed as $271 \mu \mathrm{mol} \mathrm{g}^{-1}$ wet mass.

272 Exposure of fish to experimental conditions for tissue 273 sampling

274 Normoxic fish were individually exposed to air and allowed 275 to enter into aestivation at $25^{\circ} \mathrm{C}$ in air-tight plastic contain276 ers $(7.6 \mathrm{~cm} \times 15.7 \mathrm{~cm}$, height $\times$ diameter $)$ containing $27720 \mathrm{ml}$ of water. The head space was continuously flushed $278\left(50 \mathrm{ml} \mathrm{min}^{-1}\right)$ with air $\left(20.9 \% \mathrm{O}_{2}\right.$ in $\left.\mathrm{N}_{2}\right)$ for 12 days. Hyp279 oxic fish were exposed to aerial hypoxia in similar plastic 280 containers but continuously flushed with $2 \% \quad \mathrm{O}_{2}$ in $\mathrm{N}_{2}$ 281 instead. Fish were killed on days 3, 6 or 12 with a strong 282 blow to the head. Plasma, lateral muscle, and liver were 283 sampled and kept at $-80^{\circ} \mathrm{C}$ until analysis.

\section{Determination of water content in the muscle and liver}

Water contents in muscle and liver samples ( $n=3$ each) obtained from control fish and fish aestivated in air or hypoxia for 12 days were estimated as the difference between wet mass and dry mass, and expressed as percent of wet mass tissue. The wet masses of the tissues were recorded to the nearest $0.001 \mathrm{~g}$. The tissues were then dried in an oven at $95^{\circ} \mathrm{C}$ until constant mass and the dry mass was recorded.

\section{Determination of ammonia, urea and FAAs}

The frozen samples were weighed, ground in liquid nitrogen and homogenized three times in five volumes (w/v) of 6\% TCA at $24000 \mathrm{revs}^{-1} \mathrm{~min}^{-1}$ for $20 \mathrm{~s}$ each using an UltraTurrax homogenizer (Staufen, Germany), with intervals of $10 \mathrm{~s}$ between each homogenization. The homogenate was centrifuged at $10,000 \mathrm{~g}$ at $4^{\circ} \mathrm{C}$ for $20 \mathrm{~min}$, and the supernatant obtained was kept at $-80^{\circ} \mathrm{C}$ until further analysis.

For ammonia analysis, the $\mathrm{pH}$ of the de-proteinized sample was adjusted to between 5.5 and 6.0 with $2 \mathrm{~mol} \mathrm{l}^{-1}$ $\mathrm{KHCO}_{3}$. The ammonia concentration was determined using the method of Bergmeyer and Beutler (1985). The change in absorbance at $25^{\circ} \mathrm{C}$ and $340 \mathrm{~nm}$ was monitored using a Shimadzu UV-160A spectrophotometer. Freshly prepared $\mathrm{NH}_{4} \mathrm{Cl}$ solution was used as the standard for comparison.
Urea concentration in the neutralised sample was analyzed colorimetrically according to the method of Jow et al. (1999). The difference in absorbance obtained from the sample in the presence and absence of urease (\#U7127; Sigma Chemical Co., St Louis, MO, USA) was used for the estimation of urea concentration in the sample. Urea obtained from Sigma Chemical Co. was used as a standard for comparison. Results were expressed as $\mu \mathrm{mol} \mathrm{g}^{-1}$ wet mass or $\mu \mathrm{mol} \mathrm{ml} \mathrm{ml}^{-1}$ plasma.

For FAA analysis in muscle and liver samples, the supernatant obtained was adjusted to $\mathrm{pH} 2.2$ with 4 mol $1^{-1}$ lithium hydroxide and diluted appropriately with $0.2 \mathrm{~mol}^{-1}$ lithium citrate buffer $(\mathrm{pH} 2.2)$. FAAs were analyzed using a Shimadzu LC-10A amino acid analysis system (Kyoto, Japan) with a Shim-pack ISC-07/S1504 Litype column. The total FAA (TFAA) concentration was calculated by the summation of all FAAs, while total essential FAA (TEFAA) concentration was calculated as the sum of histidine, isoleucine, leucine, lysine, methionine, phenylalanine, threonine, tryptophan and valine concentrations. Results were expressed as $\mu \mathrm{mol} \mathrm{g}^{-1}$ wet mass.

Determination of hepatic GDH enzyme activity

The liver was homogenized in five volumes (w/v) of ice-cold extraction buffer containing $50 \mathrm{mmol}^{-1}$ imidazole ( $\mathrm{pH} 7.0$ ), $1 \mathrm{mmol}^{-1}$ EDTA, $1 \mathrm{mmol}^{-1}$ EGTA, $25 \mathrm{mmol}^{-1} \mathrm{NaF}$ and $0.1 \mathrm{mmol}^{-1}$ PMSF according to the method of Ip et al. (1992). The homogenate was sonicated for $10 \mathrm{~s}$ and the sonicated sample was centrifuged at $10,000 \mathrm{~g}$ at $4^{\circ} \mathrm{C}$ for $20 \mathrm{~min}$. The supernatant obtained was passed through a Bio-Rad P6DG column (Bio-Rad Laboratories; Hercules, CA, USA) equilibrated with the elution buffer containing $50 \mathrm{mmol}^{-1}$ imidazole $\left(\mathrm{pH}\right.$ 7.0) and $1 \mathrm{mmol}^{-1}$ EDTA. The filtrate obtained was used directly for enzyme assay.

GDH (E.C. 1.4.1.3) activities were assayed according to methods of Ip et al. (1992, 1994) and Peng et al. (1994) using a Shimadzu UV 160 UV VIS recording spectrometer at at $25^{\circ} \mathrm{C}$. GDH activity in the amination direction was determined by the oxidation of NADH at $340 \mathrm{~nm}$ (millimolar extinction coefficient $\varepsilon_{340}=6.22$ ) in a reaction mixture

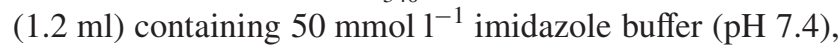
$250 \mathrm{mmol} \mathrm{l}^{-1}$ ammonium acetate, $0.15 \mathrm{mmol} \mathrm{l}^{-1} \mathrm{NADH}$, $1.0 \mathrm{mmol}^{-1} \mathrm{ADP}$ and $0.05 \mathrm{ml}$ sample. The reaction was initiated by the addition of $0.05 \mathrm{ml}$ of $\alpha$-ketoglutarate $(\alpha-\mathrm{KG})$ at a final concentration $\left(\mathrm{mmol} \mathrm{l}^{-1}\right)$ of $0.1,0.25,0.5$, or 10 . The activity obtained at $10 \mathrm{mmol}^{-1} \alpha-\mathrm{KG}$ was regarded as $V_{\text {control }}$ (approaching $V_{\max }$ ). The amination activity was expressed as $\mu \mathrm{mol}$ NADH oxidized $\min ^{-1} \mathrm{~g}^{-1}$ tissue. GDH activity in the deamination direction was determined by measuring the formation of formazan from iodonitrotetrazolium chloride at $492 \mathrm{~nm}$ (millimolar extinction coefficient $\left.\varepsilon_{492}=19.98\right)$ in a reaction mixture $(1.35 \mathrm{ml})$

\begin{tabular}{|l|l|l|l|lll|}
\hline & Large 360 & 273 & xxxx & \multicolumn{2}{|l|}{ Dispatch: 12.5.08 } & \multicolumn{2}{c|}{ No. of Pages: 13 } \\
\hline Journal & Article & MS Code & LE $\square$ & TYPESET $\square$ & CP $\square$ & DISK $\square$ \\
\hline
\end{tabular}


containing $200 \mathrm{mmol} \mathrm{l}^{-1}$ glycine-NaOH buffer (pH 9.0), $0.1 \mathrm{mmol} \mathrm{l}^{-1} \mathrm{NAD}, 0.09 \mathrm{mmol} \mathrm{l}^{-1}$ iodonitrotetrazolium chloride, $0.1 \mathrm{iu} / \mathrm{ml}$ diaphorase, $1.0 \mathrm{mmol} \mathrm{l}^{-1} \mathrm{ADP}$ and $0.15 \mathrm{ml}$ sample. This reaction was initiated by the addition of $0.1 \mathrm{ml}$ of glutamate at a final concentration $\left(\mathrm{mmol} \mathrm{l}^{-1}\right)$ of $0.5,5$ or 100 . The activity obtained at $100 \mathrm{mmol} \mathrm{l}^{-1}$ glutamate was regarded as $V_{\text {control. }}$ The deamination activity was expressed as $\mu \mathrm{mol}$ formazan formed $\mathrm{min}^{-1} \mathrm{~g}^{-1}$ tissue. In addition, amination activities at $10 \mathrm{mmol} \mathrm{l}^{-1} \alpha-\mathrm{KG}$ and deamination activity at $100 \mathrm{mmol}^{-1}$ glutamate were also determined in the absence of ADP ( $\left.V_{\text {minus ADP }}\right)$. All chemicals were obtained from Sigma Chemical Co. (St Louis, MO, USA).

Due to the small size of the liver and the various assays need to be performed, the volume of extract obtained for $\mathrm{GDH}$ assay was inadequate for the estimation of $\mathrm{Km}$ or $\mathrm{Ka}$ values, which required the determination of GDH activities at multiple substrate or activator (ADP) concentrations. Therefore, we adopted the method of expressing the results as activity ratios, which had been utilized previously by Ip et al. (1994) and Peng et al. (1994) to examine the effects of anoxia and salinity stress, respectively, on the kinetic properties of GDH from the intertidal spicunculid, Phascolosoma arcuatum. This method was originally designed by Plaxton and Storey (1985) to examine the effect of hypoxia on the kinetic properties of pyruvate kinase from the whelk, Busycotypus canaliculatum. In that study, a significantly greater enzyme activity ratio, measured at high versus low phosphoenolpyruvate concentration obtained from the normoxic animal as compared with the hypoxic animal, was taken as an indication of an increase in $\mathrm{S}_{0.5}$ of phosphoenolpyruvate for the anoxic form of pyruvate kinase (Plaxton and Storey 1985).

Determination of ammonia and urea excretion rates in control fish immersed in water

Fish were immersed individually in 20 volumes (w/v) of dechlorinated tap water in plastic aquaria at $25^{\circ} \mathrm{C}$ without aeration. Water was changed daily and no food was provided. Preliminary experiments on water sampled at 6 and $24 \mathrm{~h}$ showed that ammonia and urea excretion rates were linear up to at least $24 \mathrm{~h}$. Water $(3.6 \mathrm{ml})$ was sampled for ammonia and urea analysis every $24 \mathrm{~h}$ for 12 days. Ammonia and urea in water samples were determined according to the methods of Jow et al. (1999).

\section{Statistical analyses}

Results were presented as means \pm SEM. Time-course data in Figs. 1, 2 and 3 were analyzed using 2-way repeatedmeasures ANOVA followed by Tukey-HSD method to evaluate differences between means in Figs. 1 and 2. For
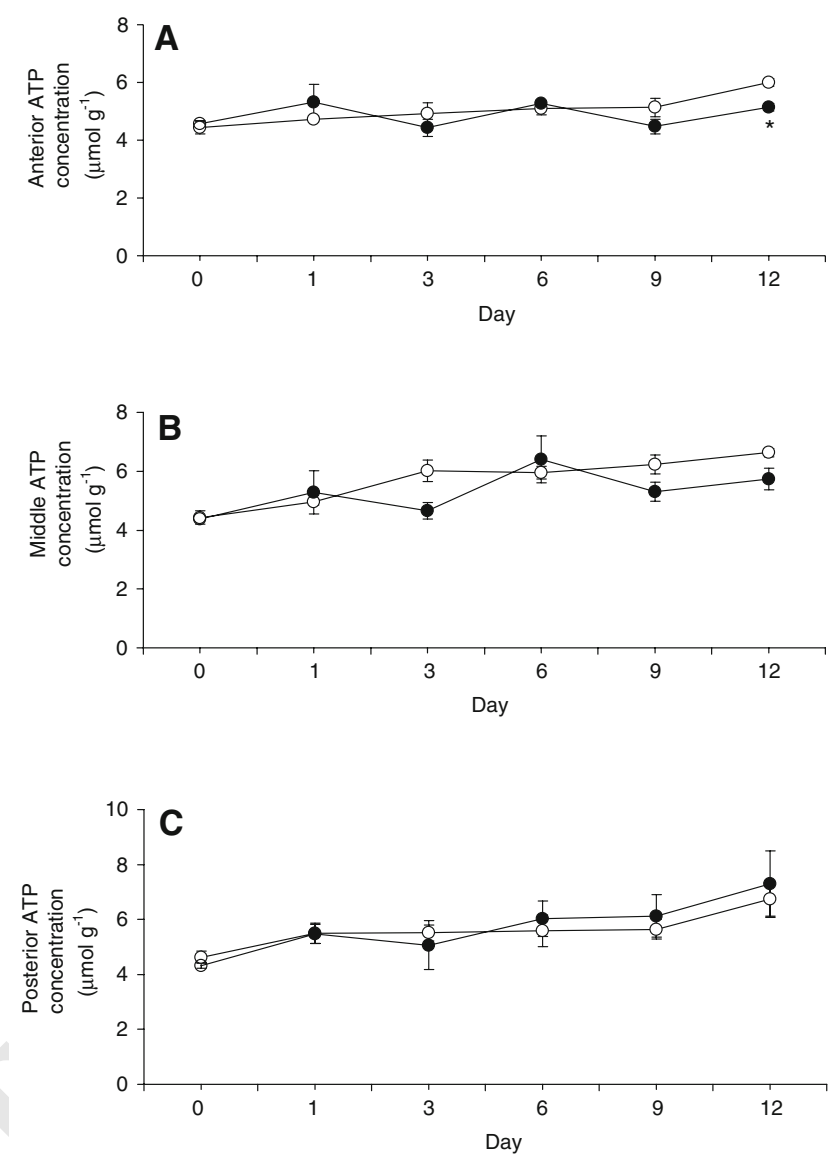

Fig. 1 Concentrations ( $\mu \mathrm{mol} \mathrm{g}{ }^{-1}$ wet mass) of adenosine triphosphate $(A T P)$, as determined by in vivo ${ }^{31} \mathrm{P}$ NMR spectroscopy, in the a anterior, $\mathbf{b}$ middle and $\mathbf{c}$ posterior regions of Protopterus annectens during 12 days of induction and maintenance of aestivation in normoxia (open circle) or hypoxia $\left(2 \% \mathrm{O}_{2}\right.$ in $\mathrm{N}_{2}$; closed circle $)$ as compared with the day 0 value (in water). Values are means $\pm \operatorname{SEM}(N=3$ for normoxia, $N=4$ for hypoxia). *Significantly different from the corresponding normoxia value in that region of the body on that day $(P<0.05)$

other data, Student's $t$ test and one-way analysis of variance (ANOVA) followed by multiple comparison of means by the Bonferroni test were used to evaluate differences between means where applicable. Differences were regarded as statistically significant at $P<0.05$.

\section{Results}

ATP and creatine phosphate in three different regions of the fish based on ${ }^{31} \mathrm{P}$ NMR spectroscopy

Twelve days of induction and maintenance of aestivation in $P$. annectens in normoxia or hypoxia did not result in significant changes in ATP (Fig. 1) or creatine phosphate (Fig. 2) concentrations in all three regions of the body. In comparison with normoxia, hypoxia led to significantly lower ATP concentration on day 12 (Fig. 1) and also significantly lower

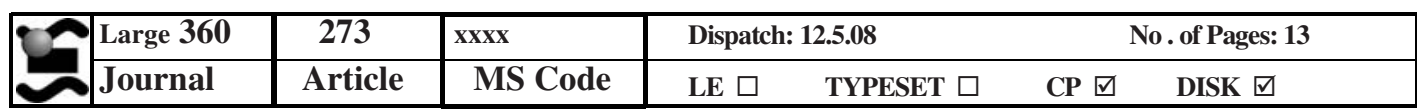



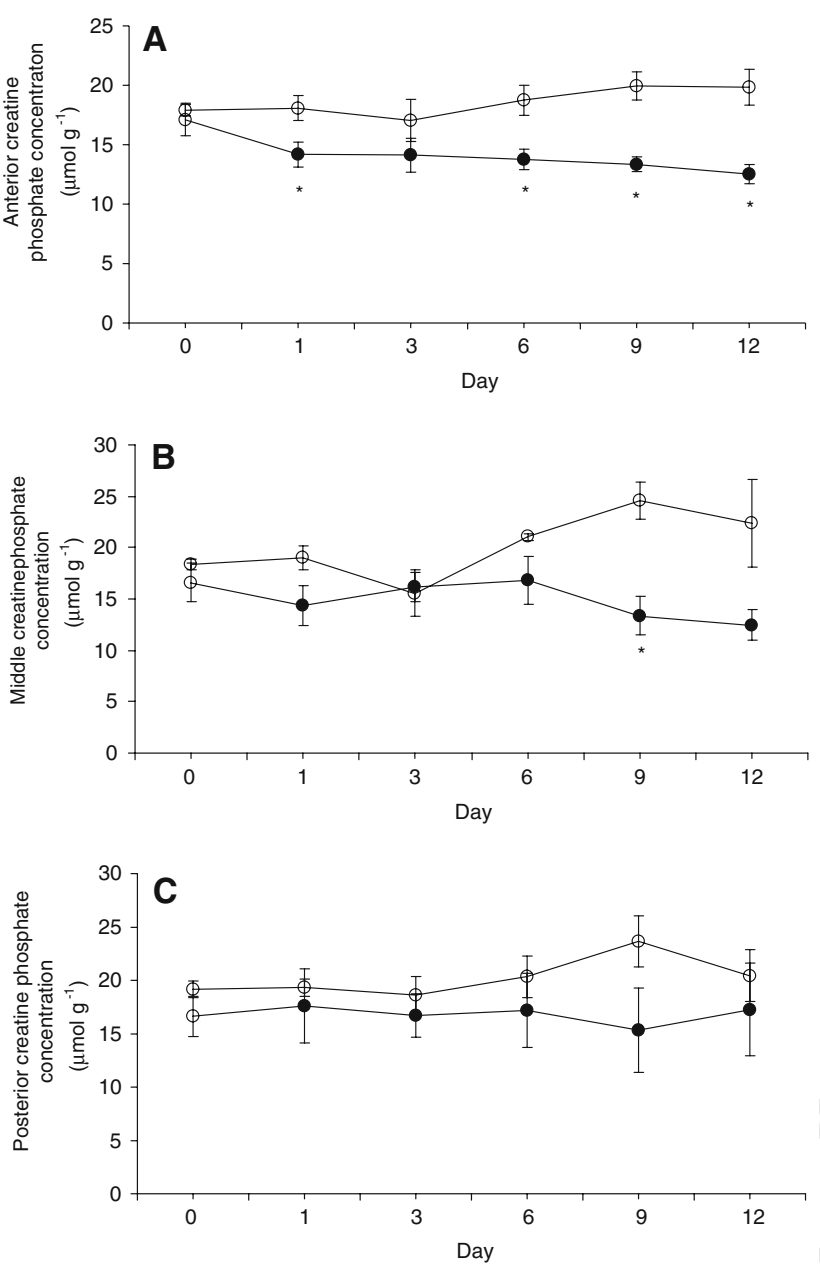

Fig. 2 Concentrations ( $\mu \mathrm{mol} \mathrm{g}^{-1}$ wet mass) of creatine phosphate $(C P)$, as determined by in vivo ${ }^{31} \mathrm{P}$ NMR spectroscopy, in the a anterior, $\mathbf{b}$ middle and $\mathbf{c}$ posterior regions of Protopterus annectens during 12 days of induction and maintenance of aestivation in normoxia (open circle) or in hypoxia $\left(2 \% \mathrm{O}_{2}\right.$ in $\mathrm{N}_{2}$; closed circle) as compared with the day 0 value (in water). Values are means $\pm \operatorname{SEM}(N=3$ for normoxia, $N=4$ for hypoxia). *Significantly different from the corresponding normoxia value in that region of the body on that day $(P<0.05)$

creatine phosphate concentration on days $1,6,9$ and 12 (Fig. 2) in the anterior region of fish undergoing induction and maintenance of aestivation. Additionally, hypoxia resulted in a significantly lower creatine phosphate concentration in the middle region of fish undergoing aestivation on day 9 .

Since these results were obtained from whole fish, they do not provide information on any specific tissue or organ. However, the detection of significant amount of creatine phosphate in the middle region of the fish, where the liver is located, was unexpected because creatine phosphate is a phosphagen found mainly in the muscle (Prosser 1973). Hence, either the creatine phosphate concentration obtained for the middle region based on ${ }^{31} \mathrm{P}$ NMR spectroscopy was contributed mainly by the muscle, or the liver actually contained an unusually high concentraton of creatine phosphate, the confirmation of which awaits future study.
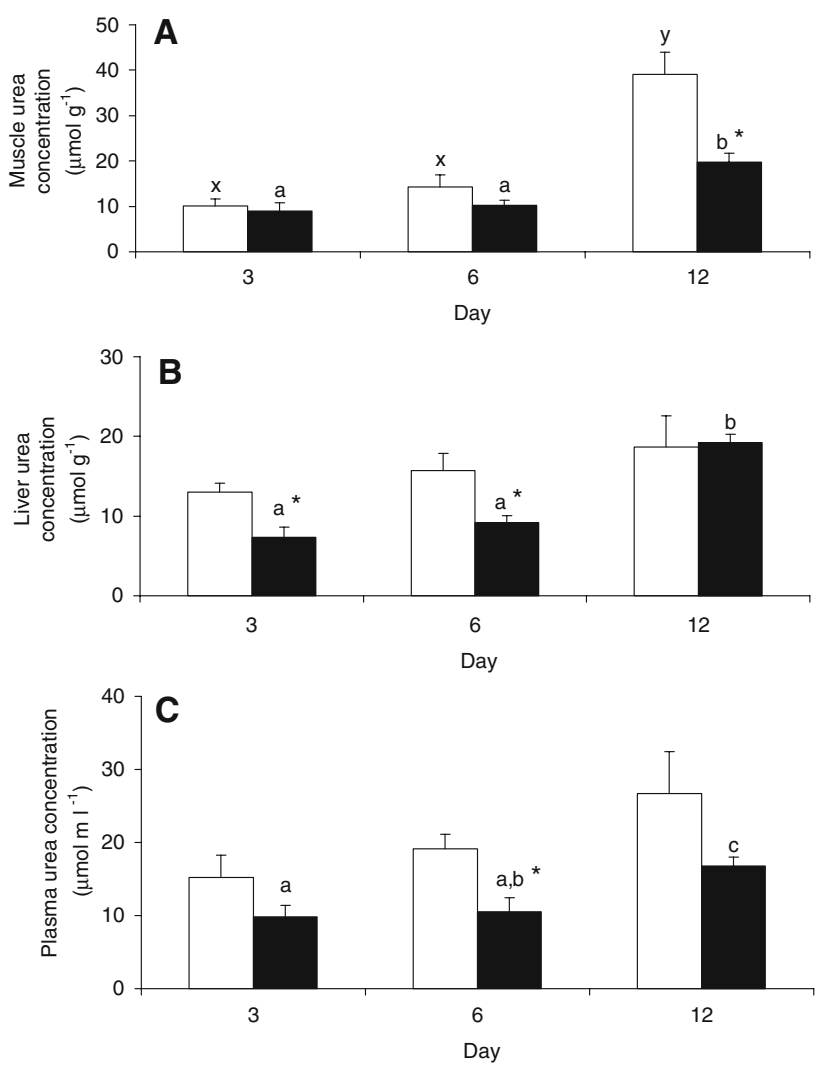

Fig. 3 Concentrations $\left(\mu \mathrm{mol} \mathrm{g}{ }^{-1}\right.$ wet mass tissue or $\mu \mathrm{mol} \mathrm{ml}^{-1}$ plasma) of urea in a muscle, $\mathbf{b}$ liver and $\mathbf{c}$ plasma of Protopterus annectens during 12 days of induction and maintenance of aestivation in normoxia (open bar) or hypoxia $\left(2 \% \mathrm{O}_{2}\right.$ in $\mathrm{N}_{2}$; closed bar). Values are means $+\operatorname{SEM}(N=5$ for control and $N=4$ for hypoxia). Means not sharing the same letter are significantly different $(P<0.05)$. $*$ Significantly different from the corresponding normoxic value $(P<0.05)$

Water contents in the muscle and liver

The water content $(n=3)$ in the muscle of $P$. annectens after 12 days of induction and maintenance of aestivation in normoxia and hypoxia were $80.1 \pm 1.8$ and $77.6 \pm 2.1 \%$, respectively, which were not significantly different from the value $(78.6 \pm 1.4 \%)$ obtained for the control fish in freshwater. Similarly, the water contents $(n=3)$ in the livers of control fish $(79.4 \pm 0.9 \%)$ and fish after 12 days of induction and maintenance of aestivation in normoxia $(78.3 \pm 0.8 \%)$ or hypoxia $(77.9 \pm 1.1 \%)$ were comparable.

Ammonia and urea concentrations

The ammonia concentrations in muscle, liver and plasma of fish kept in freshwater on day 0 were $0.48 \pm 0.28 \mu \mathrm{mol} \mathrm{g}^{-1}$, $1.07 \pm 0.35 \mu \mathrm{mol} \mathrm{g}^{-1}$, and $0.37 \pm 0.11 \mu \mathrm{mol} \mathrm{ml}^{-1}$, respectively, which were not significantly different (statistics not shown) from those values of the experimental fish exposed to normoxia or hypoxia (Table 1). There were no significant

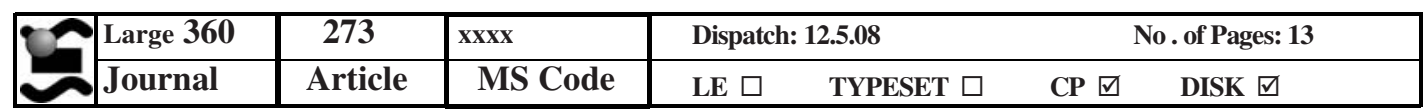




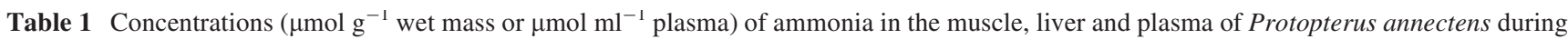
12 days of induction and maintenance of aestivation in normoxia or hypoxia $\left(2 \% \mathrm{O}_{2}\right.$ in $\left.\mathrm{N}_{2}\right)$

\begin{tabular}{|c|c|c|c|c|c|c|}
\hline \multirow[t]{2}{*}{ Tissue } & \multicolumn{3}{|l|}{ Normoxia } & \multicolumn{3}{|l|}{ Hypoxia } \\
\hline & Day 3 & Day 6 & Day 12 & Day 3 & Day 6 & Day 12 \\
\hline Muscle & $0.27 \pm 0.10$ & $0.16 \pm 0.05$ & $0.15 \pm 0.06$ & $0.22 \pm 0.23$ & $0.71 \pm 0.60$ & $0.37 \pm 0.15$ \\
\hline Liver & $1.35 \pm 0.36$ & $0.84 \pm 0.19$ & $0.47 \pm 0.06$ & $2.45 \pm 1.07$ & $2.07 \pm 1.13$ & $0.91 \pm 0.22$ \\
\hline Plasma & $0.51 \pm 0.06$ & $0.49 \pm 0.05$ & $0.37 \pm 0.04$ & $0.67 \pm 0.14$ & $0.45 \pm 0.11$ & $0.47 \pm 0.06$ \\
\hline
\end{tabular}

Results are presented as means \pm SEM ( $N=5$ for control and $N=4$ for hypoxia)

differences in the ammonia concentrations between the muscle, liver, and plasma of the normoxic fish and the hypoxic fish throughout the 12-day period (Table 1).

The urea concentrations in muscle, liver and plasma of fish kept in freshwater on day 0 were $3.18 \pm 0.86 \mu \mathrm{mol} \mathrm{g}^{-1}$, $3.64 \pm 1.05 \mu \mathrm{mol} \mathrm{g}^{-1}$, and $4.08 \pm 1.17 \mu \mathrm{mol} \mathrm{ml}^{-1}$, respectively, which were significantly lower $(P<0.05)$ than those of the experimental fish exposed to normoxia or hypoxia. On days 3 and 6, the urea concentration in the muscle of $P$. annectens exposed to hypoxia remained comparable to that of fish exposed to normoxia (Fig. 3a). On day 12, the urea concentration in the muscle of fish aestivating in hypoxia was significantly lower $(\sim 50 \%)$ than that of the fish aestivating in normoxia (Fig. 3a). By contrast, the urea concentration in the liver of fish entering into aestivation in hypoxia on days 3 and 6 was significantly lower (by 44 and $41 \%$, respectively) than that of the fish entering into aestivation in normoxia. However, there was no significant difference in the hepatic urea concentration between the fish aestivating in hypoxia and normoxia on day 12 (Fig. 3b).
As for the plasma, the urea concentration in fish entering into aestivation in hypoxia was significantly lower than that of fish entering into aestivation in normoxia on day 6 (Fig. 3c).

\section{FAA concentrations}

Muscle arginine, leucine, phenylalanine and tyrosine concentrations in fish exposed to hypoxia for 3 days, and the muscle tyrosine concentrations in fish exposed to hypoxia for 6 days were significantly higher than the corresponding value of the normoxic fish (Table 2). However, concentrations of TFAA and TEFAA in the muscle of the hypoxic fish were comparable with those of the normoxic fish throughout the 12-day period (Table 2).

By contrast, concentrations of tyrosine, TEFAA and TFAA in the liver of fish exposed to hypoxia for 3 days were significantly higher than those of fish exposed to normoxia for a similar period (Table 2). Similarly, exposure to hypoxia for 6 days resulted in significantly higher concen-

Table 2 Concentrations ( $\mu$ mol $\mathrm{g}^{-1}$ wet mass) of various free amino acids (FAAs) that showed significant changes, total essential FAA (TEFAA) and total FAA (TFAA) in the muscle and liver of Protopterus annectens during 12 days of induction and maintenance of aestivation in normoxia or hypoxia $\left(2 \% \mathrm{O}_{2}\right.$ in $\left.\mathrm{N}_{2}\right)$

\begin{tabular}{|c|c|c|c|c|c|c|c|}
\hline \multirow[t]{2}{*}{ Tissue } & \multirow[t]{2}{*}{ FAA } & \multicolumn{3}{|l|}{ Normoxia } & \multicolumn{3}{|l|}{ Hypoxia } \\
\hline & & Day 3 & Day 6 & Day 12 & Day 3 & Day 6 & Day 12 \\
\hline \multirow[t]{6}{*}{ Muscle } & Arginine & $0.0079 \pm 0.0051$ & $0.024 \pm 0.003$ & $0.026 \pm 0.001$ & $0.030 \pm 0.002 *$ & $0.021 \pm 0.002$ & $0.023 \pm 0.003$ \\
\hline & Leucine & $0.217 \pm 0.0134$ & $0.171 \pm 0.043$ & $0.195 \pm 0.019$ & $0.323 \pm 0.045^{*}$ & $0.252 \pm 0.028$ & $0.157 \pm 0.022$ \\
\hline & Phenylalanine & $0.076 \pm 0.003$ & $0.057 \pm 0.017$ & $0.040 \pm 0.003$ & $0.114 \pm 0.013^{*}$ & $0.082 \pm 0.010$ & $0.058 \pm 0.007$ \\
\hline & Tyrosine & $0.162 \pm 0.012$ & $0.208 \pm 0.025$ & $0.189 \pm 0.020$ & $0.223 \pm 0.017 *$ & $0.305 \pm 0.035^{*}$ & $0.252 \pm 0.050$ \\
\hline & TEFAA & $2.20 \pm 0.41$ & $2.07 \pm 0.41$ & $1.57 \pm 0.19$ & $3.16 \pm 0.25$ & $2.79 \pm 0.50$ & $2.40 \pm 0.43$ \\
\hline & TFAA & $3.97 \pm 0.43$ & $3.77 \pm 0.70$ & $3.52 \pm 0.48$ & $5.02 \pm 0.42$ & $5.53 \pm 0.88$ & $4.53 \pm 0.94$ \\
\hline \multirow[t]{7}{*}{ Liver } & Alanine & $0.186 \pm 0.037$ & $0.065 \pm 0.026$ & $0.095 \pm 0.033$ & $0.265 \pm 0.060$ & $0.491 \pm 0.044^{*}$ & $0.108 \pm 0.013$ \\
\hline & Glutamate & $1.61 \pm 0.307$ & $1.30 \pm 0.30$ & $1.01 \pm 0.24$ & $2.64 \pm 0.48$ & $4.34 \pm 0.227^{*}$ & $1.92 \pm 0.15^{*}$ \\
\hline & Proline & $0.140 \pm 0.069$ & $0.101 \pm 0.014$ & $0.138 \pm 0.049$ & $0.568 \pm 0.277$ & $0.298 \pm 0.071^{*}$ & $0.110 \pm 0.016$ \\
\hline & Tryptophan & $0.481 \pm 0.302$ & $1.44 \pm 0.45$ & ND & $1.16 \pm 0.284$ & $0.820 \pm 0.235$ & $0.509 \pm 0.119^{*}$ \\
\hline & Tyrosine & $0.104 \pm 0.018$ & $0.238 \pm 0.039$ & $0.144 \pm 0.015$ & $0.183 \pm 0.018^{*}$ & $0.247 \pm 0.052$ & $0.167 \pm 0.033$ \\
\hline & TEFAA & $2.13 \pm 0.43$ & $2.89 \pm 0.55$ & $1.13 \pm 0.12$ & $3.52 \pm 0.36^{*}$ & $2.96 \pm 0.80$ & $1.85 \pm 0.15^{*}$ \\
\hline & TFAA & $5.64 \pm 1.00$ & $6.77 \pm 0.78$ & $4.47 \pm 0.68$ & $8.99 \pm 0.68^{*}$ & $10.28 \pm 0.44^{*}$ & $5.57 \pm 0.31$ \\
\hline
\end{tabular}

Results represent means \pm S.E.M. $N=4$

* Significantly different from the corresponding normoxic value $(P<0.05)$

\begin{tabular}{|c|c|c|c|c|c|c|}
\hline Large 360 & 273 & $\mathbf{x x x x}$ & Dispatc & 2.5 .08 & & . of Pages: 13 \\
\hline Journal & Article & MS Code & LE $\square$ & TYPESET $\square$ & CP $\square$ & DISK च \\
\hline
\end{tabular}


trations of alanine, glutamate, proline and TFAA in the liver as compared with the corresponding normoxic values (Table 2). There were a significantly lower arginine concentration and significantly higher glutamate, histidine, tryptophan and TEFAA concentrations in the liver of fish aestivating in hypoxia as compared with fish aestivating in normoxia on day 12 (Table 2).

\section{Activity and kinetic properties of hepatic GDH}

For fish aestivating in normoxia on day 12 , there was a significant increase in the hepatic GDH amination activity, assayed in the presence of saturating concentrations of substrates and ADP, and thus a significant increase in the amination/deamination ratio as compared with fish in preparation for (day 3) or entering into aestivation (day 6) in normoxia (Table 3). Similar changes were observed in fish exposed to hypoxia, but they occurred much earlier on day 6 when the dried mucus cocoon was formed. As a result, when assayed in the presence of ADP, the GDH amination activity and amination/deamination ratio from the liver of fish entering into aestivation in hypoxia were significantly greater than those of fish entering into aestivation in normoxia on day 6 (Table 3). On day 12, there was a drastic decrease in the hepatic GDH amination activity assayed in the absence of ADP, resulting in a significant smaller amination/deamination ratio, in fish aestivating in normoxia (Table 4). It is apparent from these results that the hepatic GDH amination activity became heavily dependent on ADP activation during the maintenance phase of aestivation in normoxia. Once again, similar changes occurred but much earlier in the hypoxic fish entering into aestivating on day 6 (Table 5).

The kinetic properties of an enzyme can be presented as ratios of the enzyme activity assayed at a saturating concentration of substrate ( $\left.V_{\text {control }}\right)$ versus those assayed at sub-saturating concentrations of substrate. Specifically, an increase and a decrease of the ratio implies a decrease and an increase, respectively, in the affinity of the enzyme to the substrate. Judging by the ratios of the hepatic GDH amination activity assayed at a saturating concentration of $\alpha-\mathrm{KG}$ $\left(10 \mathrm{mmol}^{-1} ; V_{\text {control }}\right)$ versus those assayed at sub-saturating concentrations of $\alpha-\mathrm{KG}\left(0.1,0.25\right.$ or $\left.0.5 \mathrm{mmol} \mathrm{l}^{-1}\right)$, the GDH from the liver of fish entering into aestivation in normoxia on day 6 had a higher apparent affinity towards $\alpha-\mathrm{KG}$ as compared with the normoxic fish in preparation of aestivation on day 3 or undergoing aestivation on day 12 (Table 5). However, there were no significant differences in the kinetic properties of hepatic GDH in the deamination direction between fish exposed to normoxia on day 3 , enter-

and $100 \mathrm{mmol} \mathrm{l}^{-1}$ glutamate, respectively) in the presence of $1 \mathrm{mmol}^{-1} \operatorname{ADP}\left(V_{\text {control }}\right)$, and their ratios (amination/deamination) from the liver of Protopterus annectens during 12 days of induction and maintenance of aestivation in normoxia or hypoxia $\left(2 \% \mathrm{O}_{2}\right.$ in $\left.\mathrm{N}_{2}\right)$

Table 3 Specific activities of glutamate dehydrogenase (GDH) in the amination ( $\mu$ mol NADH oxidized $\min ^{-1} \mathrm{~g}^{-1}$ wet mass) and deamination ( $\mu \mathrm{mol}$ formazan formed $\mathrm{min}^{-1} \mathrm{~g}^{-1}$ wet mass) directions assayed at saturating concentrations of substrates $\left(10 \mathrm{mmol}^{-1} \alpha\right.$-ketoglutarate

\begin{tabular}{|c|c|c|c|c|c|c|}
\hline \multirow[t]{2}{*}{ GDH } & \multicolumn{3}{|l|}{ Normoxia } & \multicolumn{3}{|l|}{ Hypoxia } \\
\hline & Day 3 & Day 6 & Day 12 & Day 3 & Day 6 & Day 12 \\
\hline Amination $V_{\text {control }}$ & $16.9 \pm 0.9^{\mathrm{a}}$ & $18.6 \pm 2.7^{\mathrm{a}}$ & $32.1 \pm 4.4^{\mathrm{b}}$ & $19.2 \pm 1.1^{\mathrm{a}}$ & $28.3 \pm 1.4^{\mathrm{b} *}$ & $32.9 \pm 2.0^{\mathrm{b}}$ \\
\hline Deamination $V_{\text {control }}$ & $0.92 \pm 0.03$ & $1.51 \pm 0.33$ & $0.91 \pm 0.04$ & $0.87 \pm 0.03$ & $0.90 \pm 0.08$ & $1.07 \pm 0.12$ \\
\hline Amination/deamination & $18.0 \pm 1.0^{\mathrm{a}}$ & $13.3 \pm 1.6^{\mathrm{a}}$ & $34.5 \pm 3.4^{\mathrm{b}}$ & $22.0 \pm 2.0^{\mathrm{a}}$ & $31.2 \pm 1.1^{\mathrm{b} *}$ & $31.6 \pm 1.8^{\mathrm{b}}$ \\
\hline
\end{tabular}

Results represent means $\pm \operatorname{SEM}(N=5)$

Means not sharing the same letter are significantly different $(P<0.05)$

* Significantly different from the corresponding normoxic value $(P<0.05)$

Table 4 Specific activities of glutamate dehydrogenase (GDH) in the amination ( $\mu \mathrm{mol}$ NADH oxidized $\min ^{-1} \mathrm{~g}^{-1}$ wet mass) and deamination ( $\mu \mathrm{mol}$ formazan formed $\mathrm{min}^{-1} \mathrm{~g}^{-1}$ wet mass) directions assayed at saturating concentrations of substrates $\left(10 \mathrm{mmol}^{-1} \alpha\right.$-ketoglutarate and $100 \mathrm{mmol}^{-1}$ glutamate, respectively $)$ in the absence of $\operatorname{ADP}\left(V_{\mathrm{mi}}\right.$ nus $A D P$ ), and their ratios (amination/deamination) from the liver of Protopterus annectens during 12 days of induction and maintenance of aestivation in normoxia or hypoxia $\left(2 \% \mathrm{O}_{2}\right.$ in $\left.\mathrm{N}_{2}\right)$

\begin{tabular}{|c|c|c|c|c|c|c|}
\hline \multirow[t]{2}{*}{ GDH } & \multicolumn{3}{|l|}{ Normoxia } & \multicolumn{3}{|l|}{ Hypoxia } \\
\hline & Day 3 & Day 6 & Day 12 & Day 3 & Day 6 & Day 12 \\
\hline Amination $V_{\text {minus ADP }}$ & $2.20 \pm 0.39^{\mathrm{b}}$ & $3.82 \pm 0.6^{\mathrm{c}}$ & $0.12 \pm 0.06^{\mathrm{a}}$ & $3.04 \pm 0.25^{b}$ & $0.16 \pm 0.09^{\mathrm{a}, *}$ & $0.16 \pm 0.07^{\mathrm{a}}$ \\
\hline Deamination $V_{\text {minus ADP }}$ & $0.17 \pm 0.01$ & $0.26 \pm 0.04$ & $0.24 \pm 0.03$ & $0.16 \pm 0.02$ & $0.16 \pm 0.02$ & $0.19 \pm 0.01$ \\
\hline Amination/deamination & $13.6 \pm 2.8^{\mathrm{b}}$ & $15.0 \pm 0.5^{\mathrm{b}}$ & $0.53 \pm 0.22^{\mathrm{a}}$ & $18.9 \pm 0.8^{\mathrm{b}}$ & $0.93 \pm 0.52^{\mathrm{a}, *}$ & $0.91 \pm 0.39^{\mathrm{a}}$ \\
\hline
\end{tabular}

Results represent means $\pm \operatorname{SEM}(N=5)$

Means not sharing the same letter are significantly different $(P<0.05)$

* Significantly different from the corresponding normoxic value $(\mathrm{P}<0.05)$

\begin{tabular}{|c|c|c|c|c|c|c|}
\hline Large 360 & $\overline{273}$ & $\mathbf{x X X X}$ & Dispatc & 2.5 .08 & & of Pages: 13 \\
\hline Journal & Article & MS Code & LE $\square$ & TYPESET $\square$ & CP $\square$ & DISK ఐ \\
\hline
\end{tabular}


Table 5 Ratios of activities of glutamate dehydrogenase in the amination direction assayed in the presence of $1 \mathrm{mmol}^{-1} \mathrm{ADP}$ at saturating $\left(10 \mathrm{mmol} \mathrm{l}^{-1}\right.$, control) versus sub-saturating $(0.5,0.25$ or $\left.0.1 \mathrm{mmol}^{-1}\right)$ concentrations of $\alpha$-ketoglutarate $(\alpha \mathrm{KG})$, and ratios of enzyme activities assayed at $10 \mathrm{mmol} 1^{-1} \alpha \mathrm{KG}$ in the presence of ADP ( $1 \mathrm{mmol}^{-1}$, control) versus in the absence of ADP from the liver of Protopterus annectens during 12 days of induction and maintenance of aestivation in normoxia or hypoxia $\left(2 \% \mathrm{O}_{2}\right.$ in $\left.\mathrm{N}_{2}\right)$

\begin{tabular}{|c|c|c|c|c|c|c|}
\hline \multirow[t]{2}{*}{ GDH, amination } & \multicolumn{3}{|l|}{ Normoxia } & \multicolumn{3}{|l|}{ Hypoxia } \\
\hline & Day 3 & Day 6 & Day 12 & Day 3 & Day 6 & Day 12 \\
\hline$V_{\text {control }} / V_{0.5 \mathrm{mM} \alpha \mathrm{KG}}$ & $1.32 \pm 0.02^{\mathrm{b}}$ & $1.18 \pm 0.03^{\mathrm{a}}$ & $1.33 \pm 0.02^{b}$ & $1.29 \pm 0.05^{\mathrm{a}}$ & $1.41 \pm 0.03^{\mathrm{ab}, *}$ & $1.45 \pm 0.01^{\mathrm{b}, *}$ \\
\hline$V_{\text {control }} / V_{0.25 \mathrm{mM} \alpha \mathrm{KG}}$ & $2.06 \pm 0.04^{\mathrm{b}}$ & $1.84 \pm 0.06^{\mathrm{a}}$ & $2.18 \pm 0.06^{\mathrm{b}}$ & $2.05 \pm 0.07^{\mathrm{a}}$ & $2.34 \pm 0.06^{\mathrm{b}, *}$ & $2.41 \pm 0.02^{\mathrm{b}, *}$ \\
\hline$V_{\text {control }} / V_{0.1 \mathrm{mM} \alpha \mathrm{KG}}$ & $4.40 \pm 0.16^{\mathrm{b}}$ & $3.89 \pm 0.11^{\mathrm{a}}$ & $4.81 \pm 0.09^{\mathrm{b}}$ & $4.72 \pm 0.13$ & $5.12 \pm 0.12 *$ & $5.15 \pm 0.18$ \\
\hline$V_{\text {control }} / V_{\text {minus ADP }}$ & $8.82 \pm 1.88^{\mathrm{a}}$ & $4.88 \pm 0.14^{\mathrm{a}}$ & $110 \pm 32^{b}$ & $6.38 \pm 0.26^{\mathrm{a}}$ & $55 \pm 16(4)^{\mathrm{ab}, *}$ & $190 \pm 74^{b}$ \\
\hline
\end{tabular}

Results represent means $\pm \operatorname{SEM}(N=5)$

Means not sharing the same letter are significantly different $(P<0.05)$

* Significantly different from the corresponding normoxic value $(P<0.05)$

541 ing into aestivation on day 6 and undergoing aestivation on 542 day 12 (Table 6).

543 By contrast, the induction and maintenance of aestiva544 tion in hypoxia led to a completely different pattern of 545 changes in the kinetic properties of hepatic GDH. On days 5466 and 12, the ratios of the hepatic GDH amination activity 547 assayed at a saturating concentration of $\alpha-\mathrm{KG}$ $548\left(10 \mathrm{mmol} \mathrm{l}^{-1} ; V_{\text {control }}\right)$ versus those assayed at sub-saturat549 ing concentrations of $\alpha-\mathrm{KG}\left(0.1,0.25\right.$ or $\left.0.5 \mathrm{mmol}^{-1}\right)$ 550 obtained from the hypoxic fish were significantly greater 551 than those obtained from the normoxic fish (Table 5). 552 These results imply that the apparent affinity of GDH 553 towards $\alpha-\mathrm{KG}$ in the normoxic fish was greater than that in 554 the hypoxic fish. In addition, the ratios of the hepatic GDH 555 deamination activity assayed at a saturating concentration 556 of glutamate $\left(100 \mathrm{mmol}^{-1} ; V_{\text {control }}\right)$ versus those assayed 557 at sub-saturating concentrations of glutamate $(0.5$ or $5585 \mathrm{mmol}^{-1}$ ) obtained from fish aestivating in hypoxia were 559 significantly greater than those obtained from fish aestivat560 ing in normoxia on day 12 (Table 6), indicating an apparent 561 decrease in the affinity towards glutamate in the hypoxic 562 fish as compared with the normoxic fish.

563 An analysis of the ratios of $V_{\text {control }}$ determined in the 564 presence of ADP versus activities determined in the 565 absence of ADP $\left(V_{\text {minus ADP }}\right)$ confirmed that the hepatic

Table 6 Ratios of activities of glutamate dehydrogenase in the deamination direction assayed in the presence of $1 \mathrm{mmol}^{-1} \mathrm{ADP}$ at saturating $\left(100 \mathrm{mmol}^{-1}\right.$, control) versus sub-saturating ( 5 or $0.5 \mathrm{mmol} \mathrm{l}^{-1}$ ) concentrations of glutamate (Glu), and ratios of enzyme activities as-
GDH amination (Table 5) and deamination (Table 6) activities from $P$. annectens were dependent on ADP activation. Results obtained also confirm that the magnitude of ADP dependency for GDH in the deamination direction remained relatively constant during the 12-day period of exposure to normoxia (Table 6). However, a significantly greater dependency on ADP activation was detected for GDH, in the amination direction, extracted from livers of fish aestivating in normoxia on day 12 (Table 5) and from livers of fish entering into aestivation on day 6 or maintaining aestivation on day 12 in hypoxia (Table 5).

Ammonia and urea excretion rate in fish immersed in water

Rates of ammonia and urea excretion remained relatively constant during 12 days of fasting in water (Fig. 4). The average rates of ammonia and urea excretion over the 12day period were $2.4 \pm 0.1$ and $0.69 \pm 0.05 \mu \mathrm{mol} \mathrm{day}{ }^{-1} \mathrm{~g}^{-1}$ fish, respectively. Since the tissue urea concentrations were maintained at steady states, the average daily rate of urea synthesis can be taken as $0.69 \pm 0.05 \mu \mathrm{mol} \mathrm{day}{ }^{-1} \mathrm{~g}^{-1}$ fish. Similarly, the average daily rate of endogenous $\mathrm{N}$ production (as urea- $\mathrm{N}+$ ammonia- $\mathrm{N})$ can be taken as $(0.69 \mathrm{x}$ 2) +2.4 or $3.78 \mu \mathrm{mol} \mathrm{N} \mathrm{day}{ }^{-1} \mathrm{~g}^{-1}$.

sayed at $100 \mathrm{mmol}^{-1} \mathrm{Glu}$ in the presence of $\operatorname{ADP}\left(1 \mathrm{mmol} \mathrm{l}^{-1}\right.$, control) versus the absence of ADP from the liver of Protopterus annectens during 12 days of induction and maintenance of aestivation in normoxia or hypoxia $\left(2 \% \mathrm{O}_{2}\right.$ in $\left.\mathrm{N}_{2}\right)$

\begin{tabular}{|c|c|c|c|c|c|c|}
\hline \multirow[t]{2}{*}{ GDH, deamination } & \multicolumn{3}{|l|}{ Normoxia } & \multicolumn{3}{|l|}{ Hypoxia } \\
\hline & Day 3 & Day 6 & Day 12 & Day 3 & Day 6 & Day 12 \\
\hline$V_{\text {control }} / V_{5 \mathrm{mM} \mathrm{Glu}}$ & $1.16 \pm 0.02$ & $1.14 \pm 0.03$ & $1.06 \pm 0.03$ & $1.16 \pm 0.06$ & $1.10 \pm 0.02$ & $1.17 \pm 0.02 *$ \\
\hline$V_{\text {control }} / V_{0.5 \mathrm{mM} \mathrm{Glu}}$ & $9.89 \pm 1.54$ & $7.92 \pm 0.63$ & $5.96 \pm 1.85$ & $11.0 \pm 1.9$ & $15.6 \pm 5.6$ & $13.8 \pm 2.6^{*}$ \\
\hline$V_{\text {control }} / V_{\text {minus ADP }}$ & $5.58 \pm 0.43$ & $5.93 \pm 0.92$ & $4.05 \pm 0.52$ & $5.66 \pm 0.86$ & $5.69 \pm 0.32$ & $5.61 \pm 0.59$ \\
\hline
\end{tabular}

Results represent means \pm SEM $(N=5)$

* Significantly different from the corresponding normoxic value $(P<0.05)$

\begin{tabular}{|c|c|c|c|c|c|c|}
\hline Large 360 & 273 & $\mathbf{x x x x}$ & Dispatc & 2.5 .08 & & . of Pages: 13 \\
\hline Journal & Article & MS Code & LE $\square$ & TYPESET $\square$ & CP $\square$ & DISK च \\
\hline
\end{tabular}




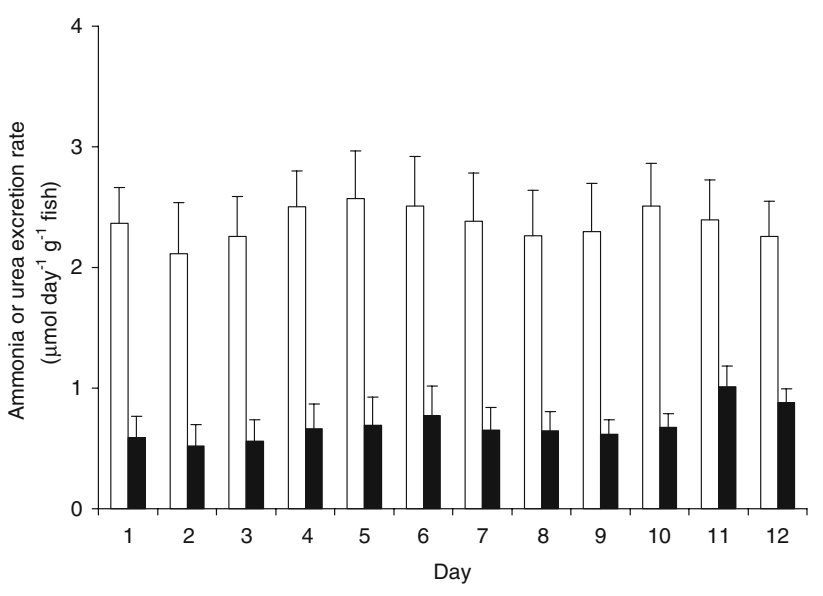

Fig. 4 Rates ( $\mu \mathrm{mol} \mathrm{day}{ }^{-1} \mathrm{~g}^{-1}$ fish) of ammonia (open bar) and urea (closed bar) excretion in Protopterus annectens during 12 days of fasting in water. Values are means $+\operatorname{SEM}(N=5)$

Calculated results for a $100 \mathrm{~g}$ fish

590
Based on the value of $3.78 \mu \mathrm{mol} \mathrm{N}$ day ${ }^{-1} \mathrm{~g}^{-1}$ (from Fig. 4), for a $100 \mathrm{~g}$ fish, this would amount to a daily $\mathrm{N}$ excretion of $378 \mu \mathrm{mol}$. Therefore, a total of $378 \mu \mathrm{mol} \mathrm{day}^{-1} \times 12$ days or $4,536 \mu \mathrm{mol} \mathrm{N}$ would have to be accounted for in a $100 \mathrm{~g}$ fish, assuming a complete impediment of ammonia and urea excretion.

For a $100 \mathrm{~g}$ fish aestivated in normoxia for 12 days, the urea-N accumulated in the muscle (55 g) and the liver $(2 \mathrm{~g})$ amounted to $2,006 \times 2$ or 4,012 $\mu \mathrm{mol} \mathrm{N}$ (from Fig. 3), which is approximately $88 \%$ of the deficit of $4,536 \mu \mathrm{mol} N$ in nitrogenous excretion. Hence, the rate of urea synthesis in the normoxic fish can be calculated as 2006/( 12 days $\times 100 \mathrm{~g})$ or $1.67 \mu \mathrm{mol} \mathrm{day}^{-1} \mathrm{~g}^{-1}$, indicating that it increased 1.67/0.69 or 2.4-fold as compared with the immersed control. Since tissue ammonia concentrations remained unchanged, the rate of endogenous $\mathrm{N}$ production (i.e. as ammonia but detoxified to urea) can be calculated as $1.67 \times 2$ or $3.34 \mu \mathrm{mol} \mathrm{N}$ day ${ }^{-1} \mathrm{~g}^{-1}$, which is only $12 \%$ lower than the value of $3.78 \mu \mathrm{mol} \mathrm{N}$ day $^{-1} \mathrm{~g}^{-1}$ for fish immersed in water.

By contrast, only $945 \mu \mathrm{mol}$ of excess urea was accumulated in muscle and liver of a $100 \mathrm{~g}$ fish in hypoxia on day 12 , which $(945 \times 2=1,890 \mu \mathrm{mol})$ represents approximately $42 \%$ of the deficit of $4,536 \mu \mathrm{mol} \mathrm{N}$ in nitrogenous excretion. Hence, the estimated average urea synthesis rate during the 12-day period is $945 /(12$ days $\times 100 \mathrm{~g})$ or $0.79 \mu \mathrm{mol} \mathrm{day}{ }^{-1} \mathrm{~g}^{-1}$, which implies that the average rate of urea synthesis in the hypoxic fish was comparable to (1.1-fold) that $\left(0.69 \mu \mathrm{mol}\right.$ day $\left.^{-1} \mathrm{~g}^{-1}\right)$ of fish immersed in water. The average rate of endogenous $\mathrm{N}$ production can be calculated as $1890 \mu \mathrm{mol} /(100 \mathrm{~g} \times 12$ days $)$ or $1.58 \mu \mathrm{mol}$ day ${ }^{-1} \mathrm{~g}^{-1}$, which represents a decrease by $58 \%$ below the rate in fish immersed in water for 12 days $(3.78 \mu \mathrm{mol}$ day ${ }^{-1} \mathrm{~g}^{-1}$ ), and such a decrease is much greater than that
$(12 \%)$ observed in fish undergoing induction and maintenance of aestivation in normoxia.

\section{Discussion}

Hypoxia led to lower ATP and creatine phosphate concentrations in certain body regions in comparison with normoxia at certain time point

Based on results obtained from in vivo ${ }^{31} \mathrm{P}$ NMR spectroscopy (Figs. 1, 2), it can be concluded that, in general, hypoxia led to lower concentrations of ATP and creatine phosphate in $P$. annectens during 12 days of aestivation as compared with normoxia. These results are novel and suggest that information available in the literature on African lungfishes aestivating in mud or an artificial device/substratum should be interpreted with caution (as suggested by Loong et al. 2008), because those information cannot be interpreted simply as effects of aestivation alone (Storey 2002), and they may actually reflect the combined effects of aestivation and hypoxia.

Induction and maintenance of aestivation in normoxia or hypoxia did not affect tissue ammonia concentrations but hypoxia led to a much smaller accumulation of urea

Although it has been reported previously that African lungfishes do not accumulate ammonia during aestivation because of increased urea synthesis and/or decreased endogenous $\mathrm{N}$ (as ammonia) production (Chew et al. 2004; Ip et al. 2005b; Loong et al. 2008), our results indicate for the first time that the magnitude of changes in urea synthesis and $\mathrm{N}$ production in fish aestivating in hypoxia differed from those in normoxia. For fish undergoing 12 days of aestivation in normoxia, there was a 2.4-fold increase in the rate of urea synthesis, but the rate of $\mathrm{N}$ production decreased by only $12 \%$, as compared with the immersed control. By contrast, the average rate of urea synthesis remained relatively unchanged (1.1-fold), but there was a prominent (58\%) decrease in $\mathrm{N}$ production, in fish aestivating in hypoxia. In normoxia, the energy status remained relatively high throughout the 12-day period, and P. annectens was able to depend mainly on increased urea synthesis, which is an energy-intensive process, to avoid ammonia toxicity. However, in hypoxia where conservation of cellular energy became an important issue, it avoided ammonia toxicity mainly through reduced $\mathrm{N}$ production.

It has been suggested previously that aestivation in air entails desiccation, and that increased tissue urea concentrations might serve the secondary function of facilitating water retention in tissues through vapour pressure depression (Campbell 1973; Loong et al. 2008). In this study, the
641

\begin{tabular}{|l|l|l|l|lll|}
\hline & Large 360 & 273 & xxxx & \multicolumn{2}{|l|}{ Dispatch: 12.5.08 } & \multicolumn{2}{c|}{ No. of Pages: 13 } \\
\hline Journal & Article & MS Code & LE $\square$ & TYPESET $\square$ & CP $\square$ & DISK $\square$ \\
\hline
\end{tabular}


670 two groups of experimental fish underwent aestivation in a 671 closed box with similar flow rates of air or $2 \% \mathrm{O}_{2}$ in $\mathrm{N}_{2}$, 672 which ensured similar rates of desiccation, but fish aestivat673 ing in hypoxia exhibited a greater magnitude of reduction 674 in $\mathrm{N}$ production and accumulated much less urea. There675 fore, our results indicate for the first time that increased 676 urea synthesis in $P$. annectens (and probably other African 677 lungfishes) during aestivation is an adaptation responding 678 primarily to ammonia toxicity, and that the involvement of 679 urea in reducing evaporative water loss could be a second680 ary phenomenon dependent on the availability of sufficient 681 oxygen.

682 Aestivation in hypoxia resulted in changes in tissue FAA 683 concentrations

684 The steady-state concentrations of tissue amino acids are 685 maintained by a balance between the rates of their degrada686 tion and production. Alteration in this balance would lead 687 to shifts in concentrations. For fish used in this study, 688 amino acids would be produced mainly through protein 689 degradation because food was withdrawn $96 \cdot \mathrm{h}$ prior to and 690 during the experiments. Since there was a significant 691 increase in the TFAA concentration in the liver of $P$. 692 annectens in hypoxia on days 3 and 6 as compared with that 693 of the normoxic fish, it is logical to assume that a reduction 694 in amino acid catabolism had occurred, resulting in the 695 accumulation of FAAs and hence an increase in the TFAA 696 concentration. In addition, there was a significant increase 697 in the TEFAA concentration in the liver of fish exposed (on 698 day 3) to, or aestivating (on day 12) in, hypoxia as com699 pared with those of the normoxic fish. Since essential 700 amino acids could not be synthesized by the fish and since 701 there was no food supply, they must have been released 702 through protein degradation. Therefore, increases in their 703 concentrations could be a result of an increase in protein 704 degradation or a decrease in their catabolism. The latter 705 seems to be a more probable proposition than the former 706 because of the needs to avoid ammonia toxicity during aes707 tivation in the absence of water.

708 Incidentally, there was a significant increase in the gluta709 mate concentration in the liver of fish aestivating in 710 hypoxia on days 6 and 12. Glutamate is a key amino acid 711 involved in the synthesis of many non-essential amino 712 acids through various transamination reactions. In addition, 713 it acts as the substrate and the product for the GDH deami714 nation and amination reactions, respectively. The increase 715 in glutamate concentration in tissues of the hypoxic fish 716 suggests an alteration in the rates of production and/or deg717 radation of glutamate, and it may also indicate a reduction 718 in glutamate transdeamination which would reduce ammo719 nia production. Overall, our results indicate that there was a 720 concerted effort in $P$. annectens to minimize energy expen- diture in relation to ammonia detoxification during aestivation in hypoxia.

Activities and properties of hepatic GDH from the liver 723 of fish during the induction and maintenance of aestivation: normoxia versus hypoxia

For fish exposed to normoxia, the activities of hepatic $\mathrm{GDH}$, in the amination and deamination directions, remained relatively constant during the induction phase ( 3 or 6 days) of aestivation. However, there was a significant increase in the GDH amination activity, with the deamination activity remained unchanged, in fish aestivating in normoxia on day 12 . Hence, GDH would act less favourably in the deamination direction during the maintenance phase of aestivation to reduce the production of ammonia through transdeamination. At the same time, the hepatic GDH amination activity, but not the deamination activity, from fish aestivating in normoxia on day 12 became highly dependent on the presence of ADP. These results indicate that transdeamination of amino acids through the hepatic GDH became responsive mainly to the cellular energy status of the fish during the maintenance phase of aestivation (day 12) in normoxia.

It has been demonstrated that hepatic GDH activity increases with increased plasma ammonia concentration in juvenile turbot and seabream exposed to environmental ammonia (Person Le Ruyet et al. 1998). However, the ammonia concentrations in various tissues of $P$. annectens exposed to normoxia (or hypoxia) remained relatively unchanged and thus it can be concluded that changes in the activity of hepatic GDH occurred primarily to reduce ammonia production, and not to detoxify ammonia during aestivation. More importantly, our results reveal that changes could occur in the amination activity of GDH without any change in its deamination activity. Hence, a cautious approach should be taken to interpret results on GDH in the literature, which involved only the determination of amination activity but with the assumption that similar changes would occur in the deamination direction.

For fish exposed to hypoxia, significant increases in the hepatic GDH amination activity, the amination/deamination ratio and the dependency of the amination activity on ADP activation occurred much earlier on day 6 , that is at the onset of aestivation, instead of day 12 . These results indicate that, decreased ammonia production through changes in the activity of hepatic GDH in $P$. annectens can be more effectively induced and exacerbated by a combination of aestivation and hypoxia then aestivation alone (in normoxia). To our knowledge, this is the first report of such a phenomenon in African lungfishes. Our results indicate that GDH was critically regulated in fish during the induction phase of aestivation in hypoxia, suppressing ammonia
726

727

728

729

730

731

732

733

734

735

736

737

738

739

740

741

742

743

744

745

746

747

748

749

750

751

752

753

754

755

756

757

758

759

760

761

762

763

764

765

766

767

768

769

770

771

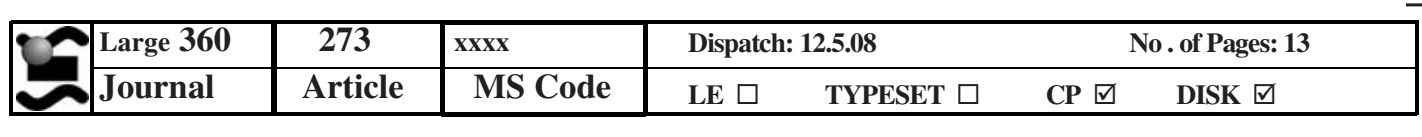




\section{Conclusion}

819 Our results indicate for the first time that $P$. annectens 820 exhibited different adaptive responses during the induction 821 and maintenance phases of aestivation in normoxia and in hypoxia. It avoided ammonia toxicity mainly through increased urea synthesis and reduced $\mathrm{N}$ production during 12 days of aestivation in normoxia and hypoxia, respectively. Hypoxia resulted in changes in activities of hepatic GDH, in the amination direction, on days 6 and 12, but similar changes occurred in the normoxic fish on day 12 only. Hence, reduction in nitrogen metabolism, and possibly in metabolic rate, occurred more prominently in response to a combined effect of aestivation and hypoxia, and a re-examination of the intricate relationships between aestivation, hypoxia and metabolic rate reduction in African lungfishes is warranted. Additionally, our results suggest that information available in the literature concerning aestivating lungfishes should be viewed with caution, especially when no indication was provided on whether aestivation occurred in normoxia or hypoxia, or on the severity of hypoxia that was involved.

\section{References}

Bergmeyer HU, Beutler HO (1985) Ammonia. In: Bergmeyer HU, Bergmeyer J, Grabl M (ed) Methods of enzymatic analysis, vol VIII. Verlag Chemie, Weinheim, pp 454-461

Brusilow SW (2002) Reviews in molecular medicine-hyperammonemic encephalopathy. Medicine 81:240-249

Campbell JW (1973) Nitrogen excretion. In: Prosser CL (ed) Comparative animal physiology, 3rd edn. Saunders College Publishing, Philadelphia, pp 279-316

Chew SF, Ong TF, Ho L, Tam WL, Loong AM, Hiong KC, Wong WP, Ip YK (2003) Urea synthesis in the African lungfish Protopterus dolloi-hepatic carbamoyl phosphate synthetase III and glutamine synthetase are upregulated by 6 days of aerial exposure. J Exp Biol 206:3615-3624

Chew SF, Chan NKY, Loong AM, Hiong KC, Tam WL, Ip YK (2004) Nitrogen metabolism in the African lungfish (Protopterus dolloi) aestivating in a mucus cocoon on land. J Exp Biol 207:777-786

Chew SF, Wilson JM, Ip YK, Randall DJ (2006) Nitrogen excretion and defense against ammonia toxicity. In: Val A, Almedia-Val, Randall DJ (ed) Fish physiology, vol 21, the physiology of tropical fishes. Academic Press, London, pp 307-396

Cooper JL, Plum F (1987) Biochemistry and physiology of brain ammonia. Physiol Rev 67:440-519

Felipo V, Butterworth RF (2002) Neurobiology of ammonia. Prog Neurobiol 67:259-279

Fishman AP, Pack AI, Delaney RG, Gallante RJ (1987) Estivation in Protopterus. In: Bemis WE, Burggren WW, Kemp NE (eds) The biology and evolution of lungfishes. Alan R. Liss Inc, New York, pp 163-179

Graham JB (1997) Diversity and natural history. In: Air-breathing fishes: evolution, diversity and adaptation. Academic Press, San Diego, pp 223-240

Hermenegildo C, Marcaida G, Montoliu C, Grisolia S, Minana M, Felipo V (1996) NMDA receptor antagonists prevent acute ammonia toxicity in mice. Neurochem Res 21:1237-1244

Herrero-Yraola A, Bakhit SMA, Franke P, Weise C, Schweiger M, Jorcke D, Ziegler M (2001) Regulation of glutamate dehydrogenase by reversible ADP-riboysylation in mitochondria. EMBO J 20:2404-2412

Hochachka PW (1980) Living without oxygen. Harvard University Press, Cambridge

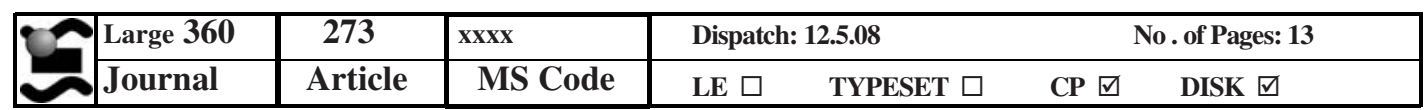


Ip YK, Chew SF, Peng KW, Lim RLW (1992) Effects of environmental anoxia on the amino acid compositions and kinetic properties of glutamate dehydrogenase in three body parts of Phascolosoma arcuatum. J Exp Mar Biol Ecol 165:125-132

Ip YK, Chew SF, Randall DJ (2001) Ammonia toxicity, tolerance and excretion. In: Wright PA, Anderson PM (ed) Fish physiology, vol 20. Academic Press, San Diego, pp 109-148

Ip YK, Chew SF, Randall DJ (2004) Five tropical air-breathing fishes, six different strategies to defend against ammonia toxicity during aerial exposure. Physiol Biochem Zool 77:768-782

Ip YK, Peh BK, Tam WL, Lee SLM, Chew SF (2005a) Changes in salinity and ionic compositions act as environmental signals to induce a reduction in ammonia production in the African lungfish Protopterus dolloi. J Exp Zool 303A:456-463

Ip YK, Peng KW, Chew SF, Lim RLW, Tan GQ (1994) Ammonia production and kinetic properties of glutamate dehydrogenase in the sipunculid Phascolosoma arcuatum exposed to anoxia. Mar Biol 119:261-266

Ip YK, Yeo PJ, Loong AM, Hiong KC, Wong WP, Chew SF (2005b) The interplay of increased urea synthesis and reduced ammonia production in the African lungfish Protopterus aethiopicus during 46 days of aestivation in a mucus cocoon on land. J Exp Zool 303A: $1054-1065$

Janssens PA (1964) The metabolism of the aestivating African lungfish. Comp Biochem Physiol 11:105-117

Janssens PA, Cohen PP (1966) Ornithine-urea cycle enzymes in the African lungfish Protopterus aethiopicus. Science 152:358-359

Janssens PA, Cohen PP (1968a) Biosynthesis of urea in the estivating African lungfish and in Xenopus laevis under conditions of water shortage. Comp Biochem Physiol 24:887-898

Janssens PA, Cohen PP (1968b) Nitrogen metabolism in the African lungfish. Comp Biochem Physiol 24:879-886

Jow LY, Chew SF, Lim CB, Anderson PM, Ip YK (1999) The marble goby Oxyeleotris marmoratus activates hepatic glutamine synthetase and detoxifies ammonia to glutamine during air exposure. J Exp Biol 202:237-245

Kemp GJ, Meyerspeer M, Moser E (2007) Absolute quantification of phosphorus metabolite concentrations in human muscle in vivo by ${ }^{31}$ P MRS: a quantitative review. NMR Biomed 20:555-565

Loong AM, Hiong KC, Lee SLM, Wong WP, Chew SF, Ip YK (2005) Ornithine-urea cycle and urea synthesis in African lungfishes, Protopterus aethiopicus and Protopterus annectens, exposed to terrestrial conditions for 6 days. J Exp Zool 303A:354-365

Loong AM, Pang CYM, Hiong KC, Wong WP, Chew SF, Ip YK (2008) Increased urea synthesis and/or suppressed ammonia production in the African lungfish, Protopterus annectens: aestiva- tion in air versus aestivation in mud. J Comp Physiol B 178:351363

Melzner F, Bock C, Pörtner HO (2006) Critical temperatures in the cephalopod Sepia officinalis investigated using in vivo ${ }^{31} \mathrm{P}$ NMR spectroscopy. J Exp Biol 209:891-906

Mommsen TP, Walsh PJ (1989) Evolution of urea synthesis in vertebrates: the piscine connection. Science 243:72-75

Peng KW, Chew SF, Ip YK (1994) Free amino-acids and cell volume regulation in the Sipunculid Phascolosoma arcuatum. Physiol Zool 67:580-597

Perry SF, Euverman R, Wang T, Loong AM, Chew SF, Ip YK, Gilmour KM (2008) Control of breathing in African lungfish (Protopterus dolloi): A comparison of aquatic and cocooned (terrestrialized) animals. Resp Physiol Neurobiol 160:8-17

Person Le Ruyet J, Boeuf G, Zambonino Infante J, Helgason S, Le Roux A (1998) Short-term physiological changes in turbot and seabream juveniles exposed to exogenous ammonia. Comp Biochem Physiol 119A:511-518

Plaitakis A, Zaganas J (2001) Regulation of human glutamate dehydrogenase: implications for glutamate, ammonia and energy metabolism in brain. J Neurosci Res 66:899-908

Plaxton WC, Storey KB (1985) Tissue specific isozyme of pyruvate kinase in the channelled whelk, Busycotypus cannaliculatum: enzyme modification in response to environmental anoxia. J Comp Physiol 155B:291-296

Prosser CL (1973) Muscles. In: Prosser CL (ed) Comparative animal physiology, 3rd edn. Saunders College Publishing, Philadelphia, pp 279-316

Rose C (2002) Increased extracellular brain glutamate in acute liver failure: decreased uptake or increased release? Metab Brain Dis $17: 251-261$

Smith HW (1930) Metabolism of the Lungfish, Protopterus aethiopicus. J Biol Chem 88:97-130

Smith HW (1935) The metabolism of the lungfish II. Effect of feeding meat on metabolic rate. J Cell Comp Physiol 6:335-349

Storey KB (2002) Life in the slow land: molecular mechanisms of estivation. Comp Biochem Physiol A 133:733-754

Thatcher BJ, Storey KN (2001) Glutamate dehydrogenase from liver of euthermic and hibernating Richardson's ground squirrels: evidence for two distinct enzyme forms. Biochem Cell Biol 79:11-19

Wood CM, Walsh PJ, Chew SF, Ip YK (2005) Greatly elevated urea excretion after air exposure appears to be carrier mediated in the slender lungfish (Protopterus dolloi). Physiol Biochem Zool 78:893-907

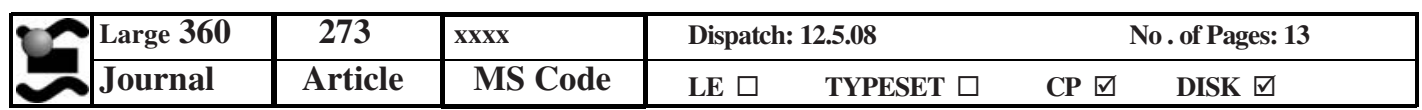

